\title{
PENGAWASAN KEPALA SEKOLAH DALAM MENINGKATKAN PRODUKTIVITAS SEKOLAH
}

\author{
Oleh: Asmariani, MA
}

\begin{abstract}
Abstrak
Kepala sekolah mengemban tugas untuk mengatur sedemikian rupa bagaimana lembaga pendidikan yang dipimpinnya dapat menjadi maju dan terdepan. Salah satu tuganya adalah melakukan pengawasan kepada warga sekolahnya, baik itu para majlis guru, pegawai TU, pegawai Pustaka sekalipun penjaga sekolah dan Cleaning Service (CS). Adanya pengawasan yang dilakukan oleh kepala sekolah tentunya diharapkan akan menghasilkan produktivitas sekolah yang mencapai target yang telah direncanakan di awal. Untuk jangka panjang juga bermanfaat untuk perbaikan perencanaan kegiatan berikutnya agar tidak berulang-ulang dilakukan kesalahan. Produktivitas adalah pengukuran seberapa baik sumber daya yang digunakan bersama di dalam organisasi untuk menyelesaikan suatu kumpulan hasil-hasil. Produktivitas sekolah berbeda dengan hasil produksi benda dan jasa yang mudah dihitung dan diukur. Produktivitas sekolah berkaitan dengan bagaimana menghasilkan lulusan baik secara kuantitatif, sehingga pada akhirnya diperoleh lulusan yang berkualitas sesuai dengan kebutuhan masyarakat dan perkembangan zaman.
\end{abstract}

Kata Kunci: Pengawasan Kepala Sekolah, Produktivitas Sekolah

\section{A. Pendahuluan}

Dalam sebuah lembaga pendidikan tidak lepas peran sumber daya manusia, karena ini merupakan salah satu faktor penentu maju mundurnya lembaga tersebut. Sehingga seorang pemimpin 


\section{$2 \quad \frac{\text { JURNAL AL-AFKAR }}{\text { Vol. III, No. 2, OkTober } 2015}$}

(kepala sekolah) harus berusaha meningkatkan kinerja sumber daya manusia seperti mengadakan pengawasan, motivasi serta bimbingan terhadap tenaga kependidikan dengan menetapkan tingkat kinerja tenaga kependidikan yang dilakukan berdasarkan standar patokan yang telah disusun.

Pengawasan disebut juga kontrol manajerial (controling) merupakan salah satu fungsi manajemen dalam lembaga pendidikan. Fungsi tersebut mutlak harus dilakukan dalam setiap organisasi atau lembaga pendidikan karena ketidakmampuan atau kelalaian untuk melakukan fungsi tersebut akan sangat mempengaruhi pencapaian tujuan organisasi atau lembaga pendidikan. ${ }^{1}$

Adanya pengawasan kepala sekolah yang efektif akan menghasilkan Produktivitas dalam dunia pendidikan berkaitan keseluruhan proses perencanaan, penataan dan pendayagunaan sumber daya untuk merealisasikan tujuan pendidikan secara efektif dan efesien. ${ }^{2}$ Produktivitas sekolah baik secara kuantitas dan kualitasnya dapat ditingkatkan melalui peningkatan profesionalitas kepemimpinan kepala sekolah dan tenaga kependidikan serta budaya organisasi sekolah yang mendukung baik secara langsung maupun tidak langsung.

\section{B. Pembahasan}

\section{Pengawasan Sekolah}

a) Pengertian Pengawasan

\footnotetext{
1 Sulistyorini, Manajemen Pendidikan Islam Konsep, Strategi dan Aplikasi cet. Ke-1, (Yogyakarta : Teras, 2009), h. 136.

2 E. Mulyasa, Menjadi Kepala Sekolah Profesional, (Bandung : PT Remaja Rosdakarya, 2006), h.134.
} 
Menurut Dale yang dikutif oleh Andri Feriyanto \& Endang Shyta Triana dalam buku yang berjudul Pengantar Manajemen (3 IN 1), bahwa:

... the modern concept of control... provides a historical record of what has happened... and provides date the enable the... to take corrective steps.

(Konsep modern kontrol memberikan catatan sejarah tentang apa yang telah terjadi dan memberikan tanggal memungkinkan untuk mengambil langkah korektif).

Hal ini berarti bahwa pengawasan tidak hanya melihat sesuatu dengan seksama dan melaporkan hasil kegiatan mengawasi, tetapi juga mengandung arti memperbaiki dan meluruskannya sehingga mencapai tujuan yang sesuai dengan apa yang telah direncanakan. ${ }^{3}$

Menurut Mockler yang dikutif oleh Enkoswara dalam buku Manajemen Pendidikan yang ditulis oleh Maisah menyatakan pengawasan adalah suatu usaha sistematis untuk menetapkan standar pelaksanaan dengan tujuan-tujuan perencanaan, merancang sistem informasi umpan balik, membandingkan kegiatan nyata dengan standar yang telah ditetapkan sebelumnya, menentukan dan mengukur penyimpangan-penyimpangan, serta mengambil tindakan koreksi yang diperlukan untuk menjamin bahwa semua sumber daya pendidikan diperlukan dengan cara paling efektif dan efesien dalam tujuan-tujuan organisasi. ${ }^{4}$

Pengawasan adalah keseluruhan upaya pengamatan pelaksanaan kegiatan opersional guna manajemen bahwa kegiatan

\footnotetext{
3 Andri Eriyanto \& Endang Shyta Triana, Pengantar Manajemen (3 IN 1) cet.1, (Yogyakarta : Mediatera, 2015), h. 63.

4 Maisah, Manajemen Pendidikan, (Ciputat: Referensi (Gaung Persada Press Group), 2013), h. 143-144.
} 


\section{JURNAL AL-AFKAR \\ Vol. III, No. 2, Oktober 2015}

tersebut sesuai dengan rencana yang telah ditetapkan sebelumnya. ${ }^{5}$ Pengawasan adalah mengevalusikan pelaksanaan kerja, dan jika perlu memperbaiki apa yang sedang dikerjakan untuk menjamin tercapainya hasil-hasil menurut rencana. Pengawasan adalah dalam bentuk pemeriksaan untuk memastikan bahwa apa yang sudah dikerjakan adalah juga yang dimaksudkan untuk membuat seorang manajer waspada terhadap suatu persoalan potensial sebelum persoalan itu menjadi serius. ${ }^{6}$

Dari beberapa pendapat di atas, maka dapat disimpulkan bahwa pengawasan adalah suatu proses yang sistematis dengan melakukan pengamatan terhadap pelaksanaan kegiatan tidak hanya melaporkan hasilnya tetapi juga memberikan solusi guna perbaikan dimasa yang akan datang sehingga tujuan yang telah direncanakan dapat dicapai dengan efektif dan efesien.

Pengawasan merupakan suatu proses pengamatan terhadap pelaksanaan seluruh kegiatan di lembaga/organisasi untuk menjamin agar semua pekerjaan yang sedang dilaksanakan berjalan sesuai dengan rencana yang telah ditentukan. Kegiatan dalam pengawasan ini antara lain mencakup hal-hal sebagai berikut : ${ }^{7}$

1) Mencegah terjadinya penyimpangan-penyimpngan dari rencana yang telah ditetapkan sebelumnya.

2) Meluruskan kembali penyimpangan-penyimpangan yang terjadi dalam proses pelaksanaan.

3) Membimbing personil dalam rangka peningkatan

5 Ramayulis, Ilmu Pendidikan Islam, (Jakarta : Kalam Mulia, 2004), h. 250.

6 Goerge R. Terry \& Leslie W. Rue, Dasar-dasar Manajemen, (Jakarta : PT Bumi Aksara, 2014), h. 232.

7 M. Sulthan Masyhud, Manajemen Profesi Kependidikan, (Yogyakarta, Kurnia Kalam Semesta, 20114), h. 132. 
kemampuan bekerja.

4) Memperoleh umpan balik (feed back) tentang hasil pelaksanaan program kerja yang sedang dilaksanakan.

5) Pengawasan dilakukan baik secara langsung, maupun tidak langsung.

6) Pelaksanaan pengawasan hendaknya tidak menganggu proses kerja, tetapi justru dapat meningkatkan efektivitas, efesien dan relevansi program.

Dari penjabaran beberapa hal tersebut di atas, maka dapat diketahui bahwa sebagai seorang kepala sekolah dalam melaksanakan pengawasan itu tidak hanya sekedar mengawasi, mengoreksi, tetapi memberikan bimbingan kepada tenaga kependidikan dengan memberikan solusi beberapa alternatif pemecahan masalah yang sedang dihadapi dengan tidak mengganggu proses kerja tenaga kependidikan itu sendiri.

\section{b) Jenis-Jenis Pengawasan}

Ada beberapa jenis pengawasan yang dapat dilakukan adalah sebagai berikut : ${ }^{2}$

1) Pengawasan intern dan ekstern

Pengawasan intern adalah pengawasan yang dilakukan oleh orang atau badan yang ada di dalam lingkungan unit organisasi yang bersangkutan yang dilakukan secara langsung atau melekat atau rutin. Sedangkan pengawasan ekstern adalah pemeriksaan yang dilakukan oleh unit pengawasan yang berada di luar unit organisasi yang diawasi.

8 Andri Eriyanto \& Endang Shyta Triana, Pengantar Manajemen, (3 IN 1) cet.1.., h. 64-65. 


\section{JURNAL AL-AFKAR \\ Vol. III, No. 2, Oktober 2015}

2) Pengawasan preventif dan represif

Pengawasan preventif adalah pengawasan yang dilakukan terhadap suatu kegiatan sebelum kegiatan itu dilaksanakan, sehingga dapat mencegah terjadinya penyimpangan. Sedangkan pengawasan represif adalah pengawasan yang dilakukan terhadap suatu kegiatan setelah kegiatan itu dilakukan.

3) Pengawasan aktif dan pasif

Pengawasan dekat (aktif) dilakukan sebagai bentuk pengawasan yang dilaksanakan di tempat kegiatan yang bersangkutan. Sedangkan pengawasan jauh (pasif) melakukan pengawasan melalui penelitian dan pengujian terhadap surat-surat pertanggungjawaban yang disertai dengan bukti-bukti penerimaan dan pengeluaran.

Sebagai seorang pemimpin di sekolah, hendaknya kepala sekolah bisa bijak dalam memilih jenis pengawasan mana yang tepat sesuai dengan karakter tenaga kependidikan di lembaga pendidikan agar yang ia pimpin agar program pengawasan tersebut ada umpan balik sehingga tujuan yang telah direncanakan tercapai dengan efektif dan efesien tanpa ada tenaga kependidikan yang merasa terganggu dengan adanya program pengawasan tersebut.

\section{c) Tahap-Tahap Pengawasan}

Dalam melaksanakan pengawasan, ada beberapa tahap-tahap proses pengawasan adalah sebagai berikut : ${ }^{9}$

1) Tahap penetapan standar. Tujuannya adalah sebagai

9 Ibid, h. 65-66. 
sasaran, kuota, dan tetap pelaksanaan kegiatan yang digunakan sebagai patokan dalam pengambilan keputusan.

2) Tahap penentu pengukuran pelaksanaan kegiatan. Digunakan sebagai dasar atas pelaksanaan kegiatan yang dilakukan secara tepat.

3) Tahap pengukuran pelaksanaan kegiatan. Beberapa poses yang berulang-ulang dan kontiniu, yang berupa pengamatan, laporan, metode, pengujian, dan sampel.

4) Tahap perbandingan pelaksanaan dengan standar dan analisa penyimpangan. Digunakan untuk mengetahui penyebab terjadinya penyimpangan dan menganalisanya, juga digunakan sebagai alat pengambilan keputusan.

5) Tahap pengambilan tindakan koreksi. Bila diketahui dalam pelaksanaannya terjadi penyimpangan, dimana perlu ada perbaikan dalam pelaksanaan.

Agar tidak terjadi kesalahan atau kekeliruan dalam melaksanakan pengawasan, hendaknya kepala sekolah memperhatikan dengan sebaik mungkin terhadap tahap-tahap pengawasan secara sistematis agar tidak mengalami kesulitan dan dilakukan berulang-ulang supaya mendapatkan hasil yang optimal.

\section{d) Bentuk-Bentuk Pengawasan}

Menurut J. Mocker dalam T. Hani Handoko yang dikutif oleh Barnawi \& M. Arifin, ada beberapa tipe-tipe dalam pengawasan adalah sebagai berikut : ${ }^{10}$

${ }^{10}$ Barnawi \& M. Arifin, Manajemen Sarana Eु Prasarana Sekolah, (Jogjakarta : Ar-Ruzz Media, 2012), h. 29-30. 
Vol. III, No. 2, Oktober 2015

1) Pengawasan pendahulu (feedforward control, steering controls). Pengawasan ini dirancang untuk mengantisipasi masalahmasalah atau penyimpangan-penyimpangan standar atau tujuan dan memungkinkan koreksi dibuat sebelum kegiatan dilaksanakan. Pengawasan ini akan lebih efektif apabila manajer mampu mendapatkan informasi akurat dan tepat pada waktunya tentang perubahan-perubahan dalam lingkungan atau tentang perkembangan terhadap tujuan yang diinginkan.

2) Pengawasan yang dilakukan bersamaan dengan pelaksanaan kegiatan (concurrent control), yaitu pengawasan Ya-Tidak, screening control atau berhenti-terus, dilakukan suatu kegiatan berlangsung. Tipe pengawasan ini merupakan proses ketika aspek tertentu dari suatu prosedur dan syarat harus disetujui terlebih dahulu sebelum kegiatan dilanjutkan.

3) Pengawasan umpan balik (feedback control atau pastaction controls), yaitu mengukur hasil-hasil suatu kegiatan yang telah diselesaikan, sebab-sebab penyimpangan dari rencana atau standar ditentukan, dan penemuanpenemuan diterapkan untuk kegiatan-kegiatan serupa di masa yang akan datang.

Bentuk-bentuk pengawasan tersebut di atas sangat bermanfaat bagi organisasi. Kombinasi antara ketiga bentuk dapat meminimalisasi kesenjangan antara harapan organisasi dengan kenyataan yang terjadi. ${ }^{11}$ Dalam hal memilih bentuk pengawasan, kepala sekolah hendaknya harus menyesuaikan antara penyimpangan yang telah terjadi dengan bentuk

${ }^{11}$ Ibid, h. 30. 
pengawasan yang akan digunakan sehingga dalam memberikan bimbingan terhadap tenaga kependidikan tidak salah tindakan dan tujuan yang sebelumnya dapat tercapai.

\section{e) Syarat-Syarat Pengawasan}

Adapun yang menjadi syarat-syarat dalam pengawasan yaitu pengawasan harus mendukung sifat dan kebutuhan kegiatan, pengawasan harus melaporkan setiap penyimpangan yang terjadi, pengawasan harus mempunyai pandangan ke depan, pengawasan harus objektif, teliti, dan sesuai dengan standar, pengawasan harus luwes atau fleksibel, pengawasan harus serasi dengan pola organisasi, pengawasan harus ekonomis, pengawasan harus mudah dimengerti, pengawasan harus diikuti dengan perbaikan atau koreksi. ${ }^{12}$

Agar menghasilkan pengawasan yang baik, maka hendaknya sebelum melaksanakan pengawasan memperhatikan syarat-syarat pengawasan agar tidak salah sasaran sehingga sesuai dengan pengawasan itu sendiri dimana pengawasan itu memberikan manfaat bagi organisasi atau lembaga pendidikan.

\section{f) Prinsip-Prinsip Pengawasan}

Adapun prinsip dalam pengawasan adalah sebagai berikut $:^{13}$

1) Memastikan pelaksanaan pekerjaan sesuai rencana, sehingga harus ada perencanaan tertentu, intruksi, dan wewenang kepada bawahan (tenaga kependidikan).

2) Harus merefleksikan sifat-sifat kebutuhan dari aktivitas yang harus dievaluasi, dapat dengan segera

\footnotetext{
${ }^{12}$ Andri Eriyanto \& Endang Shyta Triana, Pengantar Manajemen (3 IN 1) cet.1.., h. 67.

${ }^{13}$ Ibid, h. 67.
} 
Vol. III, No. 2, Oktober 2015

melaporkan penyimpangan-penyimpangan. Fleksibel dapat merefleksikan pola organisasi, ekonomi, dapat dimengerti, dan dapat menjamin diadakannya tindak korektif.

\section{g) Manfaat Pengawasan}

Selain itu, ada beberapa manfaat dari pengawasan yaitu $:^{14}$

1) Untuk memberikan ruang regular bagi supervisi guna merenungkan isi dan pekerjaan mereka.

2) Untuk mengembangkan pemahaman dan keterampilan dalam bekerja.

3) Untuk menerima informasi dan perspektif lain mengenai pekerjaan seseorang.

4) Untuk menjadi dukungan, baik segi pribadi ataupun pekerjaan.

5) Untuk memastikan bahwa sebagai pribadi dan sebagai orang pekerja tidak ditinggalkan tidak perlu membawa kesulitan, masalah dan proyeksi saja.

6) Untuk memiliki ruang guna mengesplorasi dan mengekspresikan distress, restimulation pribadi, tranferensi atau counter-tranferensi yang mungkin dibawa oleh pekerja.

7) Untuk merencanakan dan memanfaatkan sumber daya pribadi dan profesional yang lebih baik.

8) Untuk menjadi pro-aktif bukan re-aktif.

9) Untuk memastikan kualitas pekerjaan.

Dari penjabaran beberapa hal di atas, maka pengawasan menjadi sangat dibutuhkan karena dapat membangun suatu

${ }^{14}$ Ibid, h. 67-68. 
komunikasi yang baik antara pemimpin organisasi dengan anggota organisasi, serta pengawasan dapat memicu terjadinya tindak pengoreksian yang tepat dalam merumuskan suatu masalah. Pengawasan lebih baik dilakukan secara langsung oleh kepala sekoah/pemimpin karena perlu adanya hak dan wewenang ketegasan seorang kepala sekolah/pemimpin dalam suatu organisasi/lembaga pendidikan. Pengawasan disarankan dilakukan secara rutin karena dapat merubah suatu lingkungan organisasi dari yang baik menjadi lebih baik lagi.

\section{h) Pengawasan yang Efektif}

Agar pengawasan yang dilaksanakan bisa berjalan secara efektif ada beberapa kriteria yang diperhatikan yaitu berkaitan erat dengan hasil yang diinginkan, objektif, lengkap, tepat pada waktunya, dan dapat diterima. Sedangkan menurut Likert yang dikutifoleh Sulistyorini dalam bukunya yang berjudul Manajemen Pendidikan Islam suatu pengawasan akan berfungsi secara efektif jika memperhatikan pada beberapa hal, yaitu sebagai berikut : ${ }^{15}$

1) Pengawasan harus memungkinkan manajer dan para pengawainya merencanakan dan mengukur prestasi kerjanya sehingga keputusannya dapat dijadikan sebagai dasar pengetahuan dan perkiraan yang dapat diinformasikan.

2) Suatu pengawasan harus memungkinkan para manajer mendeteksi devisi dari standar yang ada pada waktu mengerjakan kontrol terebut.

3) Pengawasan harus memungkinkan sebagai alat untuk

${ }^{15}$ Sulistyorini, Manajemen Pendidikan Islam Konsep, Strategi dan Aplikasi..., h. 137. 
Vol. III, No. 2, Oktober 2015

menetapkan penghargaan, penyeleksian, dan kompensasi berdasarkan suatu prestasi kerja yang sebenarnya, dari pada berdasarkan perkiraan tentang prilaku bawahannya.

4) Pengawasan harus dapat menjadi motivasi yang merangsang untuk mencapai prestasi yang lebih baik, sehingga pengawasan tersebut mampu menjelaskan sampai sejauh mana orang-orang akan diukur dan diberi suatu kesempatan untuk mengukur efektivitas yang mereka miliki.

5) Pengawasan mampu sebagai media komunikasi yang mencakup konsep-konsep umum untuk membicarakan kemajuan organisasi.

\section{i) Pengertian Kepala Sekolah}

Menurut Ramayulis, kepala sekolah secara umum adalah pemimpin sekolah atau suatu lembaga dimana tempat menerima dan memberikan pelajaran. ${ }^{16}$ Kepala sekolah merupakan motor penggerak, penentu arah kebijakan sekolah yang akan menentukan bagaimana tujuan-tujuan sekolah dan pendidikan pada umumnya direalisasikan. Kepala sekolah dituntut untuk senantiasa meningkatkan efektifitas kinerja. ${ }^{17}$ Sehingga kepala sekolah yang profesional itu sangatlah diperlukan dalam mengelola lembaga pendidikan karena kepemimpinan seorang kepala sekolah mempengaruhi terhadap kinerja tenaga kependidikan di dalam lembaga pendidikan.

Pemimpin adalah seseorang yang mempergunakan wewenang

\footnotetext{
${ }^{16}$ Ramayulis, Profesi Eु Etika Keguruan, (Jakarta,: Kalam Mulia, 2013) h. 409.

${ }^{17}$ E. Mulyasa, Manajemen Berbasis Sekolah Konsep, Strategi, dan Implementasi, (Bandung: PT Remaja Rodakarya, 2012), h. 126.
} 
dan kepemimpinannya untuk mengarahkan orang lain yang bertanggung jawab atas pekerjaan orang tersebut dalam mencapai suatu tujuan. Sedangkan kepemimpinan adalah gaya seorang pemimpin mempengaruhi bawahannya agar mau bekerja sama dan, bekerja efektif sesuai dengan perintah. ${ }^{18}$, Kepala sekolah

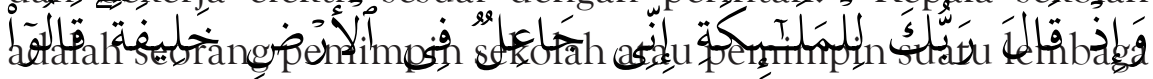
tempast menerima dan memberi pelajarąn. Şebagaimana firman

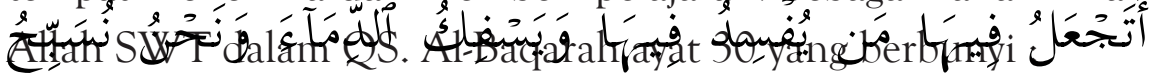

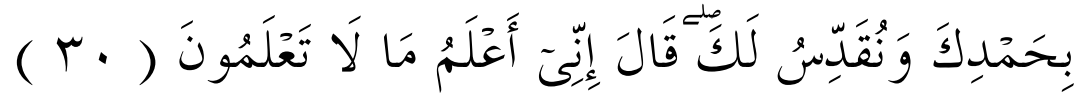

\section{Artinya :}

"Ingatlah ketika Tuhanu berfirman kepada para Malaikat: Sesungguhnya Aku hendak menjadikan seorang khalifah di muka bumi. Mereka berkata: Mengapa Engkau hendak menjadikan (khalifah) di bumi itu orang yang akan membuat kerusakan kepadanya dan menumpahkan darah, padahal kami senantiasa bertasbih dengan memuji Engkau dan memuliakan Engkau? Tuhan berfirman: Sesungguhnya Aku mengetahui apa yang tidak kamu ketahui”. (QS. Al-Baqarah : 30). ${ }^{19}$

Ayat ini mengisyaratkan bahwa pada prinsipnya bolehboleh saja seseorang memohon kepada Allah agar dijadikan

${ }^{18}$ Malayu S.P. Hasibuan, Manajemen Sumber Daya Manusia, (Jakarta : PT Bumi Aksara, 2012), h. 13.

${ }^{19}$ Yayasan Penyelenggara Penterjemah/Pentafsir Al-Qur'an, Al-Qur'an dan Terjemahannya, (Jakarta : Intermasa, 1993), h. 13. 
imam (pemimpin). Karena ia memohon kepada Allah maka harus menjalankan kepemimpinannya sesuai kemauan Allah. Yang dilarang adalah orang-orang yang meminta jabatan dan tidak dapat menjalankan karena tidak mempunyai potensi dan kemampuan. ${ }^{20}$ Jadi, apabila seseorang ingin menjadi pemimpin dalam hal ini kepala sekolah, maka hendaknya memperhatikan serta mempersiapkan kemampuan dan potensi diri terlebih dahulu baik secara fisik maupun mental agar sekolah yang dikelola tersebut tidak hanya sekedar lembaga saja melainkan ada pencapaian tujuan dan mampu menyelesaikan segala persoalan yang ada dengan kemampuan dan potensi yang dimilikinya sehingga tidak memerlukan konsultan dari laur dalam memajukan sekolah tersebut.

Dari ayatdiatas, dapat disimpulkan bahwa manusia diciptakan sebagai khalifah, dimana khalifah tersebut mengatur segala yang ada di muka bumi, dan mereka juga yang menghancurkannya. Jika kita kaitkan dengan kelapa sekolah sebagai pemimpin, maka kepala sekolah tersebut harus mampu mengatur sekolah yang ia kelola dengan memiliki kemampuan dan ilmu yang mendukung sehingga sekolah tersebut tidak mengalami kehancuran karena ulah pemimpinnya sendiri. Kepala sekolah sebagai pemimpin harus mampu membimbing dan menuntun semua warga sekolah agar menjadi lembaga pendidikan sesuai dengan fungsi dan tujuannya.

Kepala sekolah adalah seorang tenaga fungsional guru yang diberi tugas untuk memimpin suatu sekolah dimana diselenggarakan proses belajar mengajar, atau tempat dimana

${ }^{20}$ Maimunah, Manajemen Konflik dan Strategi Kepemimpinan Rasullah SAW, (Yogyakarta: Total Media, 2013), h. 38. 
terjadi interaksi antara guru yang memberi pelajaran dan murid yang menerima pelajaran. ${ }^{21}$ Secara operasional kepala sekolah adalah orang yang paling bertanggung jawab dalam menerencanakan, mengkoordinasikan, menggerakkan, dan menyelaraskan semua sumber daya madrasah serta dapat mengevaluasinya. ${ }^{22}$

Jadi, kepala sekolah itu pada awalnya sebagai guru, jika sudah diangkat menjadi kepala sekolah maka ia akan rangkap jabatan yaitu sebagai kepala sekolah dan sebagai guru. Namun, jika sekolah yang dikelolanya guru sudah layak atau memadai maka kepala sekolah itu tidak mengajar, tapi jika sekolah ia kekurangan guru maka kepala sekolah akan menjalankan tugasnya sebagai guru yaitu mengajar peserta didik.

\section{j) Syarat-Syarat Menjadi Kepala Sekolah}

Seorang kepala sekolah harus memiliki minimal beberapa syarat yaitu sebagai beriku $:^{23}$

1) Memiliki ijazah yang sesuai dengan ketentuan/peraturan yang telah ditetapkan oleh pemerintah.

2) Mempunyai pengalaman bekerja cukup, terutama di sekolah yang sejenis dengan sekolah yang ia pimpin.

3) Memiliki kepribadian yang baik, terutama sikap dan sifat-sifat kepribadian yang diperlukan bagi kepentingan pendidikan.

${ }^{21}$ Wahjosumidjo, Kepemimpinan Kepala Sekolah..., h. 83.

${ }^{22}$ Imam Musbikin, Menjadi Kepala Sekolah Yang Hebat, (Pekanbaru : Zanafa Publishing, 2013), h. 48.

${ }^{23}$ M. Ngalim Purwanto, Administrasi dan Supervisi Pendidikan, (Bandung : PT Remaja Rosdakarya, 2010), h. 106. 


\section{6 \\ JURNAL AL-AFKAR \\ Vol. III, No. 2, Oktober 2015}

4) Mempunyai keahlian dan pengetahuan luas, terutama mengenai bidang-bidang pengetahuan dan pekerjaan yang diperlukan bagi sekolah yang dipimpinnya.

5) Mempunyai ide dan inisiatif yang baik untuk kemajuan dan pengembangan sekolahnya.

Syarat-syarat tersebut mutlak harus dipenuhi oleh kepala sekolah agar dalam memimpin sudah memiliki skill yang akan dikembangkan dalam menghadapi persoalan dan kemajuan lembaga pendidikan yang dikelolanya tersebut.

\section{k) Tugas, Fungsi dan Tanggung Jawab Kepala Sekolah}

Menurut E. Mulyasa, fungsi seorang kepala sekolah yang profesional terdiri dari 7 (tujuh) karakteristik yang meliputi :

1) Kepala sekolah sebagai educator (pendidik)

Dalam melaksanakan fungsinya sebagai educator, kepala sekolah harus memiliki strategi yang tepat untuk meningkatkan profesionalisme tenaga kependidikan di sekolahnya. Menciptakan iklim sekolah yang kondusif, memberikan nasehat kepada warga sekolah, memberikan dorongan kepada seluruh tenaga kependidikan, serta melaksanakan model pembelajaran yang menarik, seperti team teaching, moving class, dan mengadakan program ekselerasi (accelecration) bagi peserta didik yang cerdas di atas normal. ${ }^{24}$

2) Kepala sekolah sebagai manajer

Dalam rangka melakukan peran dan fungsinya sebagai

\footnotetext{
${ }^{24}$ E. Mulyasa, Menjadi Kepala Sekolah Profesional..., h. 99.
} 
manajer, kepala sekolah harus memiliki strategi yang tepat untuk memberdayakan tenaga kependidikan melalui kerjasama atau kooperatif, memberi kesempatan kepada para tenaga kependidikan untuk meningkatkan profesinya, dan mendorong keterlibatan seluruh tenaga kependidikan dalam berbagai kegiatan yang menunjang program sekolah. ${ }^{25}$

3) Kepala sekolah sebagai administrator

Kepala sekolah sebagai administrator memiliki hubungan yang sangat erat dengan berbagai aktivitas pengelolaan administrasi yang bersifat pencatatan, penyusunan, dan pendokumenan seluruh program sekolah. Kemampuan mengelola administrasi personalia harus diwujudkan dalam pengembangan kelengkapan data administrasi tenaga guru, serta pengembangan kelengkapan administrasi tenaga kependidikan nonguru, seperti pustakawan, laporan, pengawai tata usaha, penjaga sekolah, dan teknisi. ${ }^{26}$

4) Kepala sekolah sebagai supervisor

Kepala sekolah sebagai supervisor harus mampu melakukan berbagai pengawasan dan pengendalian untuk meningkatkan kinerja tenaga kependidikan. Keberhasilan kepala sekolah sebagai supervisor antara lain dapat ditunjukkan oleh meningkatnya kesadaran tenaga kependidikan (guru) untuk meningkatkan kinerjanya, dan meningkatnya keterampilan tenaga kependidikan

${ }^{25}$ Ibid, h. 103

${ }^{26} \mathrm{Ibid}$, h. 107-108. 


\section{8 \\ JURNAL AL-AFKAR}

Vol. III, No. 2, Oktober 2015

(guru) dalam melaksanakan tugasnya. ${ }^{27}$

5) Kepala sekolah sebagai leader

Kepala sekolah sebagai leader harus mampu memberikan petunjuk dan pengawasan, meningkatkan kemampuan tenaga kependidikan, membuka komunikasi dua arah, dan mendelegasikan tugas. ${ }^{28}$

6) Kepala sekolah sebagai inovator

Dalam rangka melakukan peran dan fungsinya sebagai inovator, kepala sekolah harus memiliki strategi yang tepat untuk menjalin hubungan yang harmonis dengan lingkungan, mencari gagasan baru, mengintegrasikan setiap kegiatan, memberikan keteladanan kepada seluruh tenaga kependidikan di sekolah, dan mengembangkan model-model pembelajaran yang inovatif. ${ }^{29}$

7) Kepala sekolah sebagai motivator

Sebagai motivator, kepala sekolah harus memiliki strategi yang tepat untuk memberikan motivasi kepada para tenaga kependidikan dalam melakukan berbagai tugas dan fungsinya. Motivasi ini dapat ditumbuhkan melalui pengaturan lingkungan fisik, pengaturan suasana kerja, disiplin, dorongan, penghargaan secara efektif, dan penyediaan berbagai sumber belajar. ${ }^{30}$

Selain itu, menurut Ramayulis ada beberapa macam tugas kepala sekolah adalah sebagai berikut :

${ }^{27}$ Ibid, h. 115.

${ }^{28}$ Ibid, h. 115.

${ }^{29}$ Ibid, h. 118.

30 Ibid, h. 120. 


\section{1) Perencanaan (planing)}

Bila kaitannya dengan sekolah maka manajemen bermakna bahwa kepala sekolah bersama dengan timnya harus berpikir untuk menentukan sasaran-sasaran yang dikaitkan dengan kegiatan mereka sebelumnya. Kegiatan itu lebih didasari atas metode, pemikiran logis dan analisis ketimbang pada praduga. Menurut Asnawir yang dikutif oleh Ramayulis dalam bukunya yang berjudul Profesi \& Etika Keguruan, perencanaan merupakan kegiatan yang harus dilakukan pada tingkat permulaan dan merupakan aktivitas memikirkan dan memilih rangkaian tindakkan yang tertuju pada tercapainya maksud dan tujuan yang ingin dicapai. ${ }^{31}$ Adapun langkah-langkah dalam perencanaan tersebut meliputi menentukan dan merumuskan tujuan yang hendak dicapai, meneliti masalah-masalah atau pekerjaan-pekerjaan yang akan dilakukan, mengumpulkan data atau informasi yang diperlukan, menentukan tahap-tahap rangkaian tindakkan, merumuskan bagaimana masalah-masalah tersebut akan dipecahkan dan bagaimana pekerjaan tersebut harus diselesaikan, menentukan siapa yang akan melakukan dan apa yang mempengaruhi pelaksanaan dan tindakkan tersebut, dan menentukan cara bagaimana mengadakan perubahan dalam menyusun rencana.

\section{2) Pengorganisasian (organizing)}

Pengorganisasian dapat diartikan sebagai penetapan struktur dalam menentukan aktivitas-aktivitas yang dibutuhkan untuk mencapai tujuan yang telah ditetapkan bersama. Dalam pengorganisasian ini perlu diperhatikan semua kekuatan dan

\footnotetext{
${ }^{31}$ Ramayulis, Profesi E⿱ Etika Keguruan..., h. 411-414.
} 
sumber daya yang dimiliki baik sumber daya manusia maupun sumber daya non manusia. Fungsi pengoranisasian ini bertujuan agar anggota suatu organisasi dapat bekerja sama dengan orang yang akan membantu tercapainya sasaran yang telah ditetapkan. ${ }^{32}$

3) Penggerakkan (actuating)

Penggerakkan dalam pendidikan merupakan suatu uapaya untuk memberikan arahan bimbingan dan dorongan kepada seluruh sumber daya manusia dan personil yang ada dalam suatu organisasi agar dapat menjalankan tugasnya dengan kesadaran yang paling tinggi.

Dalam penggerakkan ada beberapa prinsip yaitu keteladanan, konsisten, keterbukaan, kelembutan, dan kebijakkan. Semua prinsip tersebut mempercepat dan meningkatkan kualitas penggerakkan. Fungsi dari penggerakkan ini bertujuan agar seorang kepala sekolah mampu memberikan arahan, bimbingan, maupun motivasi kepada bawahan dengan contoh tauladan yang baik agar tujuan yang telah ditetapkan bersama dapat tercapai dengan baik, efektif, dan efesien. ${ }^{33}$

\section{4) Pengawasan (controling)}

Pengawaasan dapat diartikan keseluruhan upaya penguatan pelaksanaan kegiatan operasional guna menjamin bahwa keadaan tersebut sesuai dengan rencana yang telah ditetapkan. Dalam pendidikan Islam, ada beberapa karakteristik pengawasan yaitu pengawasan bersifat material dan spritual, yang memonitor

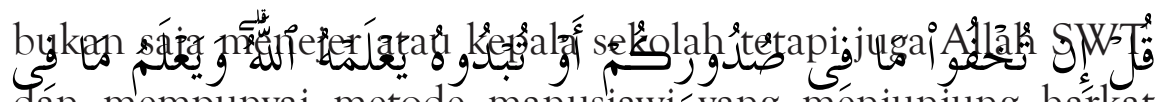
đán mempunyai metode manusiawi-yang ménjunjung hárkat

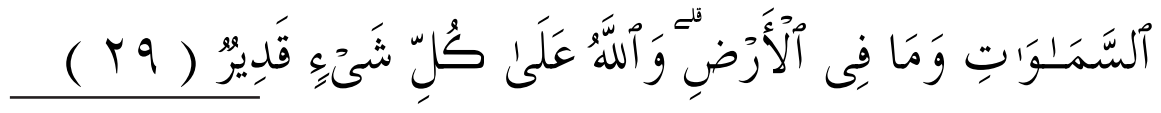

32 Ibid, h. 414.

33 Ibid, h. 416-417. 
kemanusiaan..$^{34}$ Sejalan dengan hal tersebut, Allah berfirman dalam QS Ali Imran ayat 29.

\begin{abstract}
Artinya :
"Katakanlah: "Jika kamu menyembunyikan apa yang ada dalam hatimu atau kamu melahirkannya, pasti Allah mengetahui. "Allah mengetahui apa-apa yang ada di langit dan apa-apa yang ada di bumi. Dan Allah Maha Kuasa atas segala sesuatu." (QS. Ali Imran : 29). ${ }^{35}$
\end{abstract}

Adapun maksud ayat tersebut di atas, bahwa sebagai seorang kepala sekolah berhak dan perlu melakukan pengawasan terhadap tenaga kependidikan di lembaga pendidikan yang dikelolanya dengan tujuan agar tidak terjadi penyimpangan dimana penyimpangan tersebut tidak sembunyikan dalam artian diketahui oleh kepala sekolah sehingga tidak merugikan pihak mana pun serta memberikan bimbingan terhadap kesalahan yang telah terjadi.

Dari penjabaran tugas kepala sekolah di atas, maka dapat disimpulkan bahwa kepala sekolah mempunyai tugas dalam mengelola lembaga pendidikan yaitu melakukan perencanaan, pengorganisasian, penggerakan dan pengawasan seluruh kegiatan di sekolah sehingga tujuan dapat dicapai dengna efektif dan efesien.

Kepala sekolah tidak hanya mempunyai tugas dan fungsi saja

34 Ibid, h. 417-418.

${ }^{35}$ Yayasan Penyelenggara Penterjemah/Pentafsir Al-Qur'an, Al-Qur'an dan Terjemahannya..., h. 80. 
dalam mengelola lembaga pendidikan, namun ada tanggung jawab yang harus kepala sekolah emban dalam mengelola lembaga pendidikan agar terarah dan berjalan sesuai dengan rencana. Adapun tanggung jawab kepala sekolah yaitu pembinaan ketenagaan, pembinaan kesiswaan, pembinaan sistem pengajaran, pembinaan sarana pengajaran, dan pembinaan lingkungan pendidikan dan pengajaran. ${ }^{36}$

Selain itu tanggung jawab kepala sekolah menurut Salfen Haris mengutif pendapat Blumberng sebagimana dikutif oleh Ramayaulis dalam bukunya yang berjudul Profesi dan Etika Keguruan bahwa tanggung jawab kepala sekolah adalah suatu aktivitas yang ditujukan untuk menjaga agar segala sesuatu berjalan dengan aman, mengangani atau menghindari konflik, menyembuhkan luka prsikologis, mengawasi kerja orang lain, dan menerapkan ide-ide pendidikan. ${ }^{37}$ Oleh karena itu, kepala sekolah harus mampu melaksanakan tanggung jawabnya sebaik mungkin terhadap aktivitas dan pelaksanaan kegiatan yang ada di sekolah.

\section{1) Kompetensi Kepala Sekolah Profesional}

Menurut Jamal Ma'mur Asmani, ada tujuh kompetensi kepala yang harus dikuasai oleh kepala sekolah yaitu sebagai berikut : ${ }^{38}$

Kompetensi kepribadian, artinya kepala sekolah hendaknya memiliki integritas moral yang tinggi sehingga dipercaya oleh atasan dan bawahan, tidak memiliki cacat moral seperti korupsi, mencuri, main perempuan, membunuh, main judi, minuman

${ }^{36}$ Ibid, h. 409-410.

${ }^{37}$ Ibid, h. 410.

38 Jamal Ma'mur Asmani, Tips Menjadi Kepala Sekolah Profesional, (Yogyakarta : Diva Perss, 2012), h. 86-99. 
keras, terjerat kasus narkoba, dan lain-lain.

Kompetensi manajerial, harus memiliki beberapa kemampuan seperti kemampuan mengorganiasikan dan membantu staf dalam merumuskan perbaikan pengajaran di sekolah dalam bentuk program yang lengkap, kemampuan untuk membangkitkan dan memupuk kepercayaan diri dari para guru dan anggota staf sekolah lainnya, kemampuan untuk membina dan memupuk kerja sama dalam mengajukan dan melaksanakan program-program supervisi, kemampuan untuk mendorong dan membimbing guru-guru serta segenap staf sekolah lainnya agar mereka penuh dengan kerelaan dan tanggung jawab berpartisipasi secara aktif untuk mencapai tujuan sekolah sebaik-baiknya.

Kompetensi kewirausahaan, mendorong kepala sekolah untuk kreatif menciptakan dan memanfaatkan peluang demi kemajuan sekolah seperti kreatif dalam membuat terobosan-terobosan baru bagi kemajuan sekolah misalnya mengembangkan sumber pendapatan sekolah, meningkatkan kerja sama dengan pihak lain dalam mengadakan suatu kegiatan, mengembangkan relasi, dan lain-lain.

1) Kompetensi Supervisi, dimaksudkan agar kemampuan guru dalam mengajar sesuai dengan kurikulum. Selain itu digunakan untuk memastikan pelaksanaan kegiatan sesuai dengan perencanaan khususnya supervisi pembelajaran yang menjadi inti kegiatan sekolah.

2) Kompetensi sosial, seperti bekerja sama dengan pihak lain untuk kepentingan sekolah, berpartisipasi dalam 
kegiatan sosial kemasyarakatan, memiliki kepekaan sosial terhadap orang atau kelompok lain. Kepala sekolah yang memiliki kompetensi sosial akan mampu bergaul secara santun dengan pihak terkait agar terjalinnya hubungan yang baik dan erat. ${ }^{39}$

3) Kompetensi pemikiran, kepala sekolah harus kaya pemikiran, gagasan, dan ide. Kekuatan pemikiran inilah yang akan menggerakkan perubahan dan kemajuan bagi lembaga, karena akan selalu muncul gagasan-gagasan baru yang tidak pernah habis untuk memajukan sekolah yang dipimpinnya.

4) Kompetensi spriritual, kekuatan spritual bisa menjadi filter yang kuat untuk menggapai keseimbangan dan ketenangan batin dan stabilitas moral yaitu yang bersumber dari agama.

Dari ketujuh kompetensi kepala sekolah tersebut di atas, maka dapat disimpulkan bahwa kompetensi kepala sekolah harus dikuasai dengan baik serta diaplikasikan agar lembaga pendidikan yang dikelola berjalan sesuai dengan perencanaan sebelumnya sehingga menjadi kepala sekolah yang profesional tidak hanya bermanfaat bagi sekolah itu sendiri melainkan bermanfaat juga bagi lembaga pendidikan lainnya.

Dari penjelasan di atas, maka dapat disimpulkan bahwa pengawasan kepala sekolah adalah upaya kepala sekolah dalam

\footnotetext{
${ }^{39}$ Agus Wibowo, Manager Ė Leader Sekolah Masa Depan Profil Kepala Sekolah Profesional dan Berkarakter, (Yogyakarta : Pustaka Pelajar, 2014), h. 42.
} 
menjamin setiap tenaga kependidikan dalam melaksanakan tugas dan fungsinya secara efisien, efektif, produktif dan bertanggung jawab. Selain itu, pengawasan kepala sekolah juga berfungsi sebagai alat penilaian terhadap kinerja tenaga kependidikan untuk menentukan kebijakan yang akan diambil oleh seorang kepala sekolah terhadap tenaga kependidikan yang bersangkutan, seperti promosi jabatan atau alih tugas jabatan (mutasi).

\section{Produktivitas Sekolah}

\section{a) Pengertian Produktivitas}

Konsep produktivitas pada awalnya dikemukan oleh Quesney seorang ekonom Prancis pada tahun 1776. Oleh karena itu, jadi wajar jika produktivitas senantiasa dikaitkan dengan nilai ekonomis suatu kegiatan, yaitu bagaimana mencapai hasil yang sebesar-besarnya dengan menggunakan sumber daya dan dana sekecil mungkin. ${ }^{40}$

Menurut Sjafri Mangkuprawira sebagaimana yang telah dikutif oleh Maisah dalam bukunya yang berjudul Manajemen Pendidikan, menjelaskan produktivitas adalah risio output dan input suatu produksi dalam priode tertentu. Input terdiri atas manajemen, tenaga kerja, biaya produksi, peralatan, serta waktu. Output meliputi produksi, produk penjualan, pendapatan dan kerusakan. ${ }^{41}$

Menurut Mali sebagaimana yang telah dikutif oleh Maisah dalam bukunya yang berjudul Manajemen Pendidikan, produktivitas adalah pengukuran seberapa baik sumber daya yang digunakan bersama di dalam organisasi untuk menyelesaikan

\footnotetext{
${ }^{40}$ E. Mulyasa, Manajemen Berbasis Sekolah Konsep, Strategi, dan Implementasi..., h. 92.

${ }^{41}$ Maisah, Manajemen Pendidikan..., h. 113.
} 


\section{6 \\ JURNAL AL-AFKAR \\ Vol. III, No. 2, Oktober 2015}

suatu kumpulan hasil-hasil. Sedangkan menurut Kopelman sebagaimana yang telah dikutif oleh Maisah dalam bukunya yang berjudul Manajemen Pendidikan, produktivitas adalah sebagai suatu konsepsi sistem, yang di dalam wujudnya dideskripsikan sebagai rasio yang merefleksikan bagaimana sumber daya yang ada dimanfaatkan secara efektif dan efesien untuk menghasilkan keluaran. ${ }^{42}$

Dari beberapa pengertian di atas, maka dapat disimpulkan bahwa produktivitas adalah bagaimana menghasilkan atau meningkatkan hasil keluaran dengan efektivitas dan penggunaan masukan atau sumber daya manusia dengan efesien sehingga menjadi berkualitas.

\section{b) Faktor-faktor yang Mempengaruhi Produktivitas}

Faktor-faktor yang mempengaruhi proktivitas adalah sebagai berikut : ${ }^{43}$

1) Tujuan sebagai ukuran produktivitas sangat tergantung pada proses yang dilakukan secara serius.

2) Dalam bidang pendidikan yang tujuannya fokus pada penciptaan sumber daya manusia yang berkualitas sangat tergantung pada pada proses yang sinergetik, yaitu suatu proses yang terbentuk dari berbagai faktor secara keseluruhan sadar bekerja untuk mencapai tujuan umum.

Selain faktor yang mempengaruhi produktivitas di atas, terdapat beberapa faktor-faktor penentu keberhasilan upaya peningkatan produktivitas yaitu perbaikan terus menerus,

\footnotetext{
42 Ibid, h. 114.

43 Ibid, h. 115.
} 
peningkatan mutu hasil pekerjaan, dan pemberdayaan sumber daya manusia. ${ }^{44}$

\section{c) Pengawasan Kepala Sekolah Dalam Meningkatkan Produktivitas Sekolah}

Produktivitas dalam dunia pendidikan berkaitan keseluruhan proses perencanaan, penataan dan pendayagunaan sumber daya untuk merealisasikan tujuan pendidikan secara efektif dan efesien. Produktivitas pendidikan mencakup tiga fungsi yaitu $:^{45}$

1) The administrator function (FFI) yaitu fungsi manajerial yang berkaitan dengan berbagai pelayanan untuk kebutuhan peserta didik dan guru.

2) The psychologist's production function (PPF) yaitu fungsi behavorial yang keluarnya merujuk pada fungsi pelayanan yang dapat mengubah perilaku peserta didik dalam kemampuan kognitif, keterampilan, dan sikap.

3) The economic production function (EPF) yaitu fungsi ekoomi yang keluarannya diidentifikasi sebagai lulusan yang memiliki kompetensi tinggi, sehingga ketika bekerja dapat memperoleh penghasilan tinggi melebihi biaya pendidikan yang telah dikeluarkan.

Dari beberapa fungsi-fungsi produktivitas pendidikan tersebut di atas, maka produktivitas pendidikan di sekolah dapat ditinjau dari sudut administrasi, psikologi, dan ekonomis dimana ketiga hal tersebut sangat penting dan tidak bisa dipisahkan dalam meningkatkan produktivitas sekolah.

\footnotetext{
${ }^{44}$ Sondang P. Siangan, Kiat Meningkatkan Produktivitas Kerja, (Jakarta, PT.Renaka Cipta, 2002) h. 1 0-13.

${ }^{45}$ E. Mulyasa, Menjadi Kepala Sekolah Profesional..., h. 134.
} 
Produktivitas sekolah berbeda dengan hasil produksi benda dan jasa yang mudah dihitung dan diukur. Produktivitas sekolah berkaitan dengan bagaimana menghasilkan lulusan baik secara kuantitatif, sehingga pada akhirnya diperoleh lulusan yang berkualitas sesuai dengan kebutuhan masyarakat dan perkembangan zaman. ${ }^{46}$ Untuk mencapai produktivitas sekolah secara maksimum, sekolah harus menjamin dipilihnya orang yang tepat, dengan pekerjaan yang tepat disertai kondisi yang memungkinkan bagi mereka untuk bekerja optimal. ${ }^{47}$ Dengan demikian, dalam meningkatkan produktivitas sekolah itu tidak hanya memperhatikan kualitas lulusan saja, akan tetapi personil yang ada di lembaga sekolah tersebut juga harus memiliki kemampuan karena secara tidak langsung berkualitas tidaknya lulusan itu tergantung pada kualitas tenaga kependidikan itu sendiri dan kualitas pengawasan kepala sekolah untuk perbaikan lebih baik.

\section{Kesimpulan}

Eksistensi kepala sekolah yang profesional itu sangatlah diidamkan dalam pengelolaan sebuah lembaga pendidikan, karena kepemimpinan seorang kepala sekolahlah yang mempengaruhi produktivitas sekolah tersebut dimana akan dinikmati langsung masyarakat hasilnya yaitu bagaimana hasil lulusan dari sekolah yang dipimpinnya. Salah satu tugasnya adalah melakukan pengawasan kepada bawahanya agar mencapai perbaikan yang lebih baik sesuai tujuan sekolah yang telah ditetapkan. Adapun faktor-faktor yang mempengaruhi proktivitas adalah sebagai

\footnotetext{
${ }^{46} \mathrm{Ibid}, \mathrm{h} .134$.

${ }^{47} \mathrm{Ibid}, \mathrm{h} .140$.
} 
berikut :

a. Tujuan sebagai ukuran produktivitas sangat tergantung pada proses yang dilakukan secara serius.

b. Dalam bidang pendidikan yang tujuannya fokus pada penciptaan sumber daya manusia yang berkualitas sangat tergantung pada pada proses yang sinergetik, yaitu suatu proses yang terbentuk dari berbagai faktor secara keseluruhan sadar bekerja untuk mencapai tujuan umum.

\section{DAFTAR PUSTAKA}

Agus Wibowo, 2014, Manager $\mathcal{E}$ Leader Sekolah Masa Depan Profil Kepala Sekolah Profesional dan Berkarakter, Yogyakarta : Pustaka Pelajar

Andri Eriyanto \& Endang Shyta Triana, 2015, Pengantar

Manajemen (3 IN 1) cet.1, Yogyakarta : Mediatera

Barnawi \& M. Arifin, Manajemen Sarana EF Prasarana Sekolah, Jogjakarta : Ar-Ruzz Media, 2012

E. Mulyasa, Manajemen Berbasis Sekolah Konsep, Strategi, dan Implementasi, Bandung : PT Remaja Rodakarya, 2012

Goerge R. Terry \& Leslie W. Rue, Dasar-dasar Manajemen, Jakarta:

PT Bumi Aksara, 2014

Imam Musbikin, 2013, Menjadi Kepala Sekolah Yang Hebat, Pekanbaru : Zanafa Publishing

Jamal Ma'mur Asmani, 2012,Tips Menjadi Kepala Sekolah Profesional, Yogyakarta : Diva Perss

M. Ngalim Purwanto, 2010, Administrasi dan Supervisi Pendidikan, Bandung : PT Remaja Rosdakarya 


\section{0}

Vol. III, No. 2, Oktober 2015

Maimunah, 2013, Manajemen Konflik dan Strategi Kepemimpinan Rasullah SAW, Yogyakarta : Total Media

Malayu S.P. Hasibuan, 2012, Manajemen Sumber Daya Manusia, Jakarta : PT Bumi Aksara

Ramayulis, 2004, Ilmu Pendidikan Islam, Jakarta : Kalam Mulia

Ramayulis, 2013, Profesi Ë Etika Keguruan, Jakarta,: Kalam Mulia

Sondang P. Siangan, 2002, Kiat Meningkatkan Produktivitas Kerja, Jakarta, PT.Renaka Cipta

Sulistyorini, 2009, Manajemen Pendidikan Islam Konsep, Strategi dan Aplikasi cet. Ke-1, Yogyakarta : Teras

Yayasan Penyelenggara Penterjemah/Pentafsir Al-Qur'an, 1993, al-Qur'an dan Terjemahannya, Jakarta : Intermasa 